\title{
A case study of Readers Theatre in a primary Norwegian EFL class
}

Anders Myrset, Stavanger

Ion Drew, University of Stavanger

\begin{abstract}
This article presents research on a case study of the use of Readers Theatre (RT), a group reading aloud activity in which a text is divided into small segments, in a sixth grade English as a Foreign Language (EFL) class in Norway. A mixed ability class of 27 readers, divided into groups of five to six pupils, rehearsed and performed fairy tales adapted for $R T$. The aims were to find out how the teachers and pupils experienced $R T$ and how it influenced the development of the pupils' reading, motivation and confidence. Data collection was through two teacher interviews, post-project pupil journals, lesson observations, and video recordings of the first rehearsals and performances of three of the groups. Gains were recorded in pupils' pronunciation, word recognition and fluency, especially among the struggling learners in the class. Gains were also recorded in pupils' motivation and confidence in reading aloud. Both the cognitive and affective gains support research on $R T$ among young learners in first language contexts and add to the sparse research on RT among young foreign language learners.
\end{abstract}

\section{Introduction and aims}

This article presents research on a case study of the use of Readers Theatre (RT) in a sixth grade English as a Foreign Language (EFL) class in Norway. RT is a method in which the individual members of a group take it in turns to read aloud a text divided into small segments that fit with the number of readers in the group. The text is thoroughly rehearsed before being read to an audience, for example to peers in a class. The first author followed the class of 27 learners (aged approximately 12) and their two teachers through a cycle of rehearsing and performing fairy tales adapted for RT. Data were collected through two teacher interviews, post-project pupil journals, lesson observations and video recordings of the first rehearsals and performances of three of the groups of pupils working with an RT text. The aim of the research was to find out how the teachers and pupils experienced RT and how it influenced the development of the pupils' reading, motivation and confidence in reading aloud. 
At the primary level, RT has mostly been practised and researched in first language (L1) classrooms, predominantly in the US (Casey \& Chamberlain, 2006; Forsythe, 1995; Lengeling, Malarcher \& Mills, 1996; Young \& Rasinski, 2009). Its potential in foreign language contexts, especially with young learners, is relatively unexplored both in and outside of Norway. Although some research has been conducted on RT in EFL contexts with learners at the lower secondary level in Norway (e.g. Drew \& Pedersen, 2010; Drew \& Pedersen, 2012), the authors are unfamiliar with any primary level EFL research on RT in Norway. Filling that gap is therefore one of the contributions of the present research. In addition, the authors are unfamiliar with the use of video recordings in previous research on RT, thereby strengthening the contribution the present study has made to the area of research.

RT is a method that integrates both oral and written language with an authentic communicative purpose (Rinehart, 1999). It trains pupils in the basic skills of reading and oral language and, in so doing, is in line with the priorities and competence aims in the English subject National Curriculum (LKO6) in Norway. After Year 7, pupils are expected to be able to read and understand different types of texts of varying length, to be able to read children's and youth literature, and to be able to use basic patterns for pronunciation and intonation. However, the LKO6 curriculum refrains from proposing teaching methods, thus leaving teachers with the responsibility of making appropriate choices to help pupils reach the specified competence aims. RT offers one way of training pupils' reading and oral skills.

The study addresses the following research questions:

How did the teachers and pupils experience RT in the $6^{\text {th }}$ grade EFL class?

How did RT influence the development of the pupils' reading accuracy and fluency?

What, if any, were the affective gains from using RT in the class?

\section{The principles of Readers Theatre}

With origins dating back to the Classical times, when bards would recite the epic poems to audiences (Coger \& White, 1967), RT is essentially a dramatic form of reading aloud a text in a group, either on stage as a form of drama or in a classroom as an educational method. RT can be used with a variety of text genres, for example narratives, fables, poems, speeches and factual texts. It can also be conducted in many forms and with different numbers of participants. The principle is to divide the text into small units, each read by one reader at a time. The readers alternate the reading until the whole text has been read.

Although there are many different models of RT, some with static and others with mobile readers, the two mostly commonly referred to are the traditional and the developed models (Shepard, 2004). In the traditional model the readers are in fixed positions, for example sitting or standing in a semi-circle. One traditional variant, as shown in Figure 1, involves seven readers, with the Narrator as the central one: 


\section{Nordic Journal of Modern Language Methodology}

Narrator

\author{
3
}

2
4

5

Dramatisation

Figure 1: Example of a traditional RT model, as shown in Drew and Pedersen (2010)

The reading takes place in a fixed order: Narrator, 1, 6, 2, 5, 3, 4, Narrator, and so on. At any given time, for example while reading a story, the reading may stop and be complemented by a dramatised scene performed in front of the readers. The dramatised scene may depict part of the story, for example a dialogue between two or more characters represented in the story, and would be acted out by others not involved in the reading.

In the developed model, in contrast, a clear distinction is made between those reading the parts of characters and those narrating the story (Shepard, 2004). The narrators are static, for example standing in the corners of a room, while those reading the roles of characters are free to move around while both reading and dramatising. In both models the scripts are visible to the audience.

The following example shows the beginning of The three little pigs text, one of the fairy tales used in the present study, in the developed model form.

Narrator 1: There once was a fat, old sow with three little pigs. The old sow did not have enough food to feed the three little pigs. So she sent them off to find food and to make their own way in the world. The first little pig went off and met a man carrying a bundle of straw.

Pig 1: $\quad$ Please, kind sir, please sell me that straw to build a house.

Narrator 2: Which the man did, and the first little pig built a house of straw. The house of straw was drafty and dusty. But it was a fine home for the little pig.

Pig 1: $\quad$ I build my house of straw, I do not have all day. I build my house of straw, so I can go and play.

Narrator 1: $\quad$ The second little pig met a man with a bundle of sticks.

Pig 2: $\quad$ Please, kind sir, sell me those sticks to build a house.

Narrator 2: Which the man did, and the second little pig built his house out of sticks. The house of sticks was rickety and rackety. But it was a fine home for the little pig.

Pig 2: $\quad$ I build my house of sticks, I do not have all day. I build my house of sticks, so I can go and play. 
Narrator 1: The third little pig met a man with a heavy load of bricks.

Pig 3: $\quad$ Please, kind sir, sell me those bricks to build a house....

\section{Research on RT}

Research on RT has primarily been case studies of the use and effects of RT in L1 primary classrooms (e.g. Martinez, Roser \& Strecker, 1999; Rinehart, 1999). It has shown that RT benefits both pupils' cognitive skills and their motivation and confidence to read aloud. Similar research, but to a lesser extent, has been conducted in some foreign language classroom environments (e.g. Chan \& Chan, 2009; Drew \& Pedersen, 2010), largely supporting the findings of the L1 research on RT.

Research on the effects of RT on pupils' cognitive skills has shown benefits in areas such as word recognition (Millin \& Rinehart, 1999; Samuels, 1997), pronunciation (Trousedale \& Harris, 1993), fluency (Martinez et al., 1999) and comprehension (McKay, 2008; Rasinski, 2010). Struggling readers have especially increased their reading accuracy (Rinehart, 1999), and reading speed and fluency through RT (Peebles, 2007).

In addition to the cognitive benefits of RT, a number of studies also demonstrate its affective benefits, especially increased motivation (Black \& Stave, 2007; Casey \& Chamberlain, 2006; Clementi, 2010; Millin \& Rinehart, 1999; Peebles, 2007; Worthy \& Prater, 2002). One motivating factor is the feeling of belonging to and contributing to a group performance. In this sense, RT very much adheres to a social-constructivist learning environment (Vygotsky, 1978), in which the participants collectively contribute to a meaningful and communicative language event. It also enables pupils to reach their zone of proximal development, i.e. advance their learning to the next level with the help of a more knowledgeable other (Vygotsky, 1978), e.g. a peer or teacher. Through collaboration and interaction while reading, even struggling readers feel a sense of belonging to and contributing to the group (Tyler \& Chard, 2000). Another motivating factor is the gradual growth in confidence as readers become more familiar and comfortable with the text through rehearsals (Rinehart, 1999; Uthman, 2002). In the words of a second grade pupil in one study: "I never thought I could be a star, but I was the best reader today." (Martinez et al., 1999, p.333).

One of the few studies of RT at the primary level in a foreign language context is that of Chan and Chan (2009), whose subjects were a remedial class of 20 EFL fifth graders. Prior to the RT project, the pupils had been considered as passive and lacking in confidence. They were "reluctant to communicate in English and experienced difficulty in reading aloud texts fluently and pronouncing words correctly" (Chan \& Chan, 2009, p.41). However, the pupils worked seriously during rehearsals, paying special attention to clear and loud articulation when portraying characters and reading the story. Two shy girls started to project their voices and also sought help from their peers on how to pronounce difficult words. An overwhelming 
majority of the pupils enjoyed RT and collaborating with their peers. They all claimed that they had become more confident in speaking English.

Apart from the Chan and Chan (2009) study, most of the limited research on RT in foreign language contexts has focussed on teenagers and adults. For example, Liu (2000), researching RT in the context of Asian EFL university students, discovered that RT helped to improve reading, linguistic competence, cultural awareness and confidence in target language communication. Two studies by Drew and Pedersen $(2010 ; 2012)$ focussed on RT among lower secondary EFL learners in Norway. Drew and Pedersen (2010) investigated the use of RT with struggling eighth and ninth grade EFL readers. The pupils' reading improved by working with a text in the traditional RT model. Conscious of the fact that they would be performing the text to an invited audience, the pupils asked the teacher for assistance with pronunciation and word stress. The benefits of RT were especially noticeable in the form of increased motivation and confidence to read. In another study (Drew \& Pedersen, 2012), lower secondary EFL pupils in two mainstream ninth grade classes experienced RT in three variants during an academic year: through ready-made texts, by adapting texts for RT, and finally, by making their own texts. The pupils thrived in their dual roles of performers and listeners. According to the teacher in the study, the pupils' oral presentation skills became far more advanced as a result of RT than previous pupils he had taught at the same level.

\section{Method}

Data were collected through several methods, thereby increasing the study's validity: two teacher interviews, post-project pupil journals, lesson observations and video recordings of rehearsals and performances in three groups. A mixed-ability sixth grade class of 27 pupils and their two teachers were followed through a one-week cycle of RT. Two of the pupils suffered from autism and four from dyslexia. The primary school (grades 1-7) consisted of approximately 350 pupils and was situated in an urban area. The school was approached through the first author's contact network. Two teachers were assigned to the class in question. They taught the majority of the lessons together, although one of them would normally focus on the group with learning difficulties. The pupils and the teachers agreed to take part in the research, and parental consent was given. Permission was sought and granted by the Norwegian Social Science Data Services (NSD) to conduct and disseminate the research. The first author was a participant observer who played an active role in deciding how the RT cycle would be conducted and which texts would be used.

The texts, originally written for fourth grade L1 pupils, were fairy tales adapted by Gerard (2007). The selected fairy tales, which the pupils were already familiar with in Norwegian, were The ugly duckling, Three little pigs, Thumbelina, The king's new clothes and Puss in boots. As the original English language of the scripts was considered too difficult, the first author simplified them by replacing difficult words and structures with simpler ones. The class was divided into five mixed ability groups and each group was assigned one of the texts. The RT cycle was completed during Tuesday to Friday of a school week. The pupils practised 
reading their scripts on each day from Tuesday to Thursday (one day with a 45-minute session and two days with 90-minute sessions). The groups performed the texts on the Friday, each performance lasting about 10 minutes.

The first author attended all of the English classes during the RT cycle. The observations during practice focused on how the groups rehearsed and cooperated. During these observations the researcher took field notes. The observations during the performance focused on the quality of reading, such as pronunciation, the pupils' confidence, the effectiveness of their reading as a communicative act, and the engagement of the listeners.

Video recordings, considered by Dörnyei (2007) as an ideal way of gathering data in classroom research, enabled the researchers to study and compare in detail the rehearsals and performances of three randomly selected groups. The groups were mixed ability with two of them containing one struggling reader and the third containing two struggling readers. To the authors' best knowledge, video recordings have not previously been employed in connection with RT to actually document reading progress. The recordings enabled the researchers to note and quantify mispronounced and wrongly recognised words. The ability to phonologically represent words and recognise them is essential for reading fluency in both mother tongue and foreign languages (Day \& Bamford, 1998). Inter-rater reliability was ensured by two researchers analysing and agreeing on the interpretation of the recorded data.

A ratio of the number of mispronounced words and wrongly recognised words was calculated as a percentage of the total number of different word types in each text. For example, although the The king's new clothes text contains 1387 words, only 252 of these are different word types, including both grammatical and lexical words. Different forms of the same word, e.g. climb and climbing, were counted as separate word types, as pupils may have wrongly pronounced the one form but not the other. If the same word was mispronounced or wrongly recognised more than once, or by more than one member of the group, it was still only counted as one misrepresentation. It was possible to compare the pupils' pronunciation and word recognition in the first rehearsals with that of the performances. In addition to the ratios of mispronounced words and wrongly recognised words to the total number of word types for each of the three texts analysed, a detailed overview of the actual words mispronounced and wrongly recognised in The king's new clothes text, as well as the number of each recorded for the individual members of the group, is provided as an example.

The video-recordings also enabled the researchers to study the pupils' fluency by comparing the time taken to read through the texts in each of the three recorded group's first rehearsal with the time spent on the reading during the group's performance. In addition, when reading difficult words, the pupils often used interjections, such as $e h$, as pauses or "fillers", which are common in speech but which nevertheless make language disfluent (Bortfeld et al. 2001, p.124). Examples are provided of the number of interjections (fillers) used by the pupils reading the King's new clothes text in the first rehearsal compared to the performance. 
Another source of data was two semi-structured interviews with one of the teachers, Elisabeth. She was first interviewed before the project started, focussing on her experiences of EFL teaching, especially reading, and her expectations for the RT project. The interview lasted about 45 minutes and was audio-recorded in addition to notes being taken. It was conducted at the school and in Norwegian to enable Elisabeth to express herself freely in her L1.

Journals, considered as an appropriate medium for reflection (Ary, Jacobs, Sorensen \& Walker, 2010), were used to collect data from the pupils. After the RT cycle, the pupils were asked to write in Norwegian how they had experienced RT. They were asked to write whether they would like to read the fairy tales that had been performed, what they had learned, and how much they had understood from listening to the other groups reading.

\section{Results}

\subsection{Pre-project teacher interview}

Elisabeth had a three-year Bachelor of Education degree with specialisation in English and had been teaching English at the primary level since 1985. Elisabeth was initially interviewed before the start of the RT project. She stated that there was a large gap between the struggling and proficient readers in the class. However, the struggling readers were accepted as fullyfledged members of the class and were not embarrassed or afraid to read aloud to the others. Pupils would practise reading at different times: during a 45-minute period set aside for reading each week, during spare time after they had finished other work, or when visiting the school library once a week. Reading aloud normally took place in groups or pairs, thus enabling the teacher to monitor each pupil's reading progress and provide corrective feedback where appropriate. However, many of the pupils disliked reading aloud.

Elisabeth was totally unfamiliar with RT. However, she was enthusiastic about participating in the project, with high expectations of experiencing something new:

I like to get new impulses when it comes to teaching, in this case towards teaching English. When it comes to teaching English I have not received any "professional updating" since I studied. So I am hoping to learn something that I can apply in my teaching.

Elisabeth expected RT to engage her pupils actively, provide them with the opportunity for a good deal of oral language practice, while also being enjoyable and motivating. She was aware that many of the pupils were looking forward to the project, although some were sceptical. The pupils had been informed that RT had been frequently practised in the UK and US. They were also informed that they would be given a script which they would practise 
reading in groups and then perform, and that they would hopefully benefit from participating in the RT project, thus raising their expectations.

\subsection{The RT project}

The pupils were divided into five mixed ability groups of five to six pupils. Each group was given a script, which included a summary of the story, a list of unfamiliar vocabulary with Norwegian translations, and a list of characters. The groups spent the first part of the first lesson reading the summary, discussing the story, and deciding on the roles. Each group chose a leader, who ensured that everyone agreed on how to perform the text.

The groups consisted of both proficient and struggling learners, with the former able to help the latter. For example, a boy in one group helped his peers from the start when they encountered problems with pronunciation. Pupils were highly preoccupied with improving their reading and were not embarrassed about making mistakes. The following interaction demonstrates the way this pupil helped his peers:

R1: Good afternoon, your Majesty. We are weavers.

R3: The best weavers in the entry world.

Boy: Entire.

R3: Oh, OK. The best weavers in the entire world.

During the first day, many of the pupils were clearly excited about this new form of reading, some even choosing to practise during breaks. At the end of the first day, the groups had read through their texts and divided the roles. The positive engagement with RT lasted throughout the week. The pupils practised both at home and at school and looked forward to the RT lessons.

During the rehearsal phase of the project Elisabeth would spend time with each group. Her primary focus was on helping the pupils with pronunciation and comprehension. She helped with pronunciation by giving pupils feedback on mispronounced words during their readings. She helped with comprehension by providing the pupils with explanations of words and sentences.

After three rehearsal sessions and about eight readings of each text, the pupils performed their texts on the fourth day. Some groups adopted a traditional RT approach by standing in a row and taking steps forward to read. Others employed a developed approach, with narrators in fixed positions and characters dramatising.

The groups reading The king's new clothes, The ugly duckling and The three little pigs were video-recorded during the first rehearsal and the performance. Table 1 shows the pupils' improvement in pronunciation and word recognition in these groups from the first rehearsal to performance. 
Table 1: Words mispronounced or wrongly recognised during the first rehearsal and performance of The king's new clothes, The ugly duckling and The three little pigs (as ratios of the number of different word types).

\begin{tabular}{|l|l|l|l|l|}
\hline Text & Total words & Word types & Rehearsal & Performance \\
\hline $\begin{array}{l}\text { The king's new } \\
\text { clothes }\end{array}$ & 1387 & 252 & $76(30.2 \%)$ & $23(9.1 \%)$ \\
\hline $\begin{array}{l}\text { The ugly } \\
\text { duckling }\end{array}$ & 1540 & 252 & $34(13.5 \%)$ & $10(4 \%)$ \\
\hline $\begin{array}{l}\text { The three little } \\
\text { pigs }\end{array}$ & 1395 & 253 & $40(15.8 \%)$ & $12(4.7 \%)$ \\
\hline
\end{tabular}

The figures show a marked improvement from the first rehearsal to performance in all three groups, but especially in The king's new clothes text, in which roughly every three out of ten words $(30.2 \%)$ were mispronounced or misread in the first rehearsal, but which saw the number reduced to one out of ten words $(9.1 \%)$ in the performance. The group reading The king's new clothes was the one in which there were two struggling readers, as opposed to one in the other two groups, thereby supporting the research that shows that RT benefits the reading accuracy of especially struggling readers (Rinehart, 1999).

Table 2 shows the number of mispronounced and wrongly recognised words for each member of the group reading The king's new clothes text in the first rehearsal compared to the performance.

Table 2: Individual pupils' mispronounced and misread words in The king's new clothes

\begin{tabular}{|l|l|l|l|l|}
\hline Reader & $\begin{array}{l}\text { Mispronounced } \\
\text { words first } \\
\text { rehearsal }\end{array}$ & $\begin{array}{l}\text { Mispronounced } \\
\text { words } \\
\text { performance }\end{array}$ & $\begin{array}{l}\text { Misread } \\
\text { Words first } \\
\text { rehearsal }\end{array}$ & $\begin{array}{l}\text { Misread } \\
\text { words } \\
\text { performance }\end{array}$ \\
\hline 1 & 18 & 8 & 7 & 2 \\
\hline 2 & 27 & 9 & 9 & 1 \\
\hline 3 & 9 & 3 & 4 & 0 \\
\hline 4 & 1 & 0 & 0 & 0 \\
\hline 5 & 1 & 0 & 0 & 0 \\
\hline Total & 56 & 20 & 20 & 3 \\
\hline
\end{tabular}

There was a noticeable difference between the levels within the group, and the progress of individual pupils from the rehearsal to the performance. The two readers who had struggled most with mispronounced and misread words in the first rehearsal, improved these aspects of their reading considerably during the performance. At the other end of the scale, two pupils 
whose only error was the mispronunciation of one word during rehearsals, in both cases pronounced the word correctly in the performance. A similar pattern was found in the other groups.

A detailed overview of mispronounced words (56) and wrongly recognised words (20) is provided for the group reading The king's new clothes. Table 3 illustrates mispronounced words during the first rehearsal of this group.

Table 3: Mispronounced words during the first rehearsal of The king's new clothes

\begin{tabular}{|c|c|c|c|}
\hline $\begin{array}{l}\text { Word } \\
\text { mispronounced }\end{array}$ & $\begin{array}{l}\text { Pronounced } \\
\text { during rehearsal }\end{array}$ & $\begin{array}{l}\text { Word } \\
\text { mispronounced }\end{array}$ & $\begin{array}{l}\text { Pronounced during } \\
\text { rehearsal }\end{array}$ \\
\hline admired & /odmi:red/ & marvellously & /ma:rwelu:sli/ \\
\hline approval & /oppru:vl// & mirror & /mirov/ \\
\hline burned & /braon/ & nobles & /noubles/ \\
\hline busy & /b $\Lambda \mathrm{si} /$ & nobody & /nu:bədi/ \\
\hline came & /kəm/ & pattern & /pætrən/ \\
\hline candles & / klænts/ & pleased & /pli:sed/ \\
\hline castle & /kæstel/ & putting & /putin/ \\
\hline clever & / levər/ & seemed & /si:med/ \\
\hline clothes & /klaððes//klaððe/ & sew & /su:/ \\
\hline could & /kovl/, /kovld/ & suit & /su:i:t/ \\
\hline crooks & /kroks/ & stayed & /steied/ \\
\hline dressed & /dresed/ & talked & /to:ked/ \\
\hline fit & /fait/ & their & /dər/ \\
\hline fits & /faits/ & thought & $/ \theta_{3}: \mathrm{d} /$ \\
\hline foolish & /fo:lif/ & thread & /tred/ \\
\hline group & /group/ & through & /t3:r/, /tru:/ \\
\hline held & /hoold/ & undressed & /ındresed/ \\
\hline honest & /hounəst/ & unfit & /ınfait/ \\
\hline imaginable & /Inımædzınəbəひ/ & upon & /eppn/ \\
\hline including & /Inklu:derfn/ & wanted & /wountəd/ \\
\hline indeed & /Inded/ & wearing & /wi:rıy/ \\
\hline job & /jpb/ & weave & /werv/ \\
\hline king's & $/ \mathrm{kIn} /$ & weavers & /weivorz/ \\
\hline lived & /liv/ & whatsoever & /wntsouvər/ \\
\hline looked & /loked/ & while & /wil/ \\
\hline looms & /1 $\Lambda \mathrm{ms} /$ & whole & /wol/ \\
\hline magnificent & $\begin{array}{l}\text { / mæginifəsənt/, } \\
\text { / mægifəsənt/, } \\
\text { / mægnifənt/ }\end{array}$ & worked & /w3:rked/ \\
\hline majesty & /mæjəsti/,/meıəsti/ & would & /wol/ \\
\hline
\end{tabular}


Table 3 shows that 56 words were mispronounced while rehearsing The king's new clothes the first time. These included both lexical words, e.g. clothes (pronounced /klaøðes/ or /klavðe/), grammatical words, e.g. upon (pronounced /eppn/), and past tense - ed verb endings, e.g. talked (pronounced/to:ked/). There was also evidence of Norwegian negative interference, e.g. the verb marched pronounced as /ma:r $\int 3^{2}: \mathrm{red} /$, which is similar to the Norwegian past tense marsjerte, a verb with the same meaning as English marched.

Table 4 shows words wrongly recognised by the pupils during the first rehearsal of The king's new clothes text.

Table 4: Words wrongly recognised in The king's new clothes first rehearsal

\begin{tabular}{|l|l|l|l|}
\hline Word in the text & $\begin{array}{l}\text { Read during first } \\
\text { rehearsal }\end{array}$ & Word in the text & $\begin{array}{l}\text { Read during first } \\
\text { rehearsal }\end{array}$ \\
\hline admit & admin & he & I have \\
\hline amazing & magazine & his & this, the \\
\hline anyone & anybody & how & who \\
\hline assist & assistant & imagine & image \\
\hline are & is & is & are \\
\hline beauty & beautiful & pretended & presented \\
\hline but & buy & the & this, he \\
\hline could & would, cloud & these & they \\
\hline doesn't & don't & this & that, the, there \\
\hline entire & entry & who & so \\
\hline
\end{tabular}

As Table 4 illustrates, 20 words, especially grammatical ones such as the definite article the and the pronouns he, his, this and these, were wrongly recognised in the first rehearsal of The king's new clothes, usually as another grammatical word. In contrast, although lexical words were often mispronounced (see Table 3), fewer of these (e.g. imagine instead of image) seemed to be confused with other words.

Table 5 shows which words were still mispronounced or misread in the performance of The King's new clothes.

Table 5: Mispronounced and wrongly recognised words in The king's new clothes performance

\begin{tabular}{|c|c|c|c|}
\hline Word in the text & $\begin{array}{l}\text { Read during } \\
\text { performance }\end{array}$ & Word in the text & $\begin{array}{l}\text { Read during } \\
\text { performance }\end{array}$ \\
\hline amazing & /eimeizin/ & majesty & 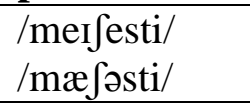 \\
\hline approval & /æpru:væl/ & marched & /ma:rJ3:red/ \\
\hline are & Is & marvellously & 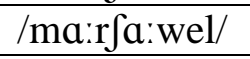 \\
\hline
\end{tabular}




\begin{tabular}{|c|c|c|c|}
\hline cloth & /kləひð/ & pattern & /pæteren/ \\
\hline crooks & /kroks/ & pleased & /pli:sed/ \\
\hline foolish & /fo:lif/ & riches & /raisis/ \\
\hline group & /group/ & suit & /si:t/ \\
\hline honest & /hounəst/ & sew & /si:a/ \\
\hline how & Who & stayed & /stered/ \\
\hline imagine & image & weavers & /weivarz/ \\
\hline imaginable & /Imədzi:bel/ & working & /v3r:rkin/ \\
\hline magnificent & /mægIfəsənt/ & & \\
\hline
\end{tabular}

It was interesting to note that the steepest learning curve was among the struggling readers. Two of the readers in the The king's new clothes group clearly struggled with pronunciation and reading fluency during the first rehearsals, but showed considerable improvement in these respects during the performance. The same applied to a girl reading the part of one of the narrators in The three little pigs.

Table 6 shows how reading speed was reduced from the first rehearsals to the performances in the three video-recorded groups.

Table 6: Comparison of reading speed in the first rehearsals and performances of The king's new clothes, The ugly duckling and The three little pigs

\begin{tabular}{|l|l|l|l|}
\hline Text & $\begin{array}{l}\text { First rehearsal time } \\
\text { (minutes and } \\
\text { seconds) }\end{array}$ & $\begin{array}{l}\text { Performance time } \\
\text { (minutes and } \\
\text { seconds) }\end{array}$ & Time difference \\
\hline The three little pigs & 11.40 & 10.18 & 1.22 \\
\hline The ugly duckling & 14.18 & 12.06 & 2.12 \\
\hline $\begin{array}{l}\text { The king's new } \\
\text { clothes }\end{array}$ & 16.33 & 9.42 & 6.5 \\
\hline
\end{tabular}

The performance readings took less time in all three groups, with the greatest difference occurring in the reading of The king's new clothes, which was read 6.5 minutes faster in the performance than in the first rehearsal.

Finally, Table 7 shows the number of fillers used by the pupils reading The king's new clothes text in the first rehearsal compared to the performance.

Table 7: Number of fillers in the first rehearsal and performance of The king's new clothes

\begin{tabular}{|l|l|l|}
\hline Reader & Fillers first rehearsal & Fillers performance \\
\hline 1 & 70 & 4 \\
\hline 2 & 53 & 10 \\
\hline 3 & 12 & 4 \\
\hline
\end{tabular}




\begin{tabular}{|l|l|l|}
\hline 4 & 3 & 1 \\
\hline 5 & 4 & 1 \\
\hline
\end{tabular}

All of the readers in the The king's new clothes group reduced the number of fillers from the first rehearsal to the performance, especially Readers 1 and 2. The most marked example was Reader 1, who used 70 fillers in the first reading. This high number of fillers was a likely consequence of his uncertainty over the pronunciation or meaning of a number of words in the text, for example: "Good afternoon, $e h . .$. your Majesty. We are $e h .$. weavers." Repeated readings of the text helped this pupil to reduce the number of fillers from 70 to four, thereby improving his reading fluency considerably. The same trend, although to a lesser extent, applied to the other readers in the group and to the readers in the other groups, for example a struggling reader in the The three little pigs group, whose reduction of fillers was from 67 to 11 .

\subsection{The pupil journals}

In their post-project journal, roughly 22 of the pupils stated that they would like to read one or more of the fairy tales and 23 responded that they had learned new words and how to pronounce them. One of the pupils had discovered that one could learn a good deal by cooperating with other pupils. Another, the boy who had helped his peers with pronunciation throughout the first week, discovered that he was better at speaking English than he realised. One pupil wrote: "It was lots of fun and I learned a lot at the same time. I was really looking forward to the Friday, when we were going to perform. I also enjoyed watching the other groups."

As an audience, the majority of the pupils had understood parts or most of the performances. However, the groups that had used a developed model of RT had been easier to understand than those using a traditional model. One pupil wrote: "I understood most of it, but it was easier to understand the groups who were acting." Although some of the struggling pupils had problems understanding the other performances, they all wrote that it had been fun both performing and watching the other groups. The process of practising had been the most important aspect of RT for them.

\subsection{The second teacher interview}

When asked about how she had experienced RT, Elisabeth replied:

Before the project started I was excited to see how the pupils would respond to RT, and how such a heterogeneous group of pupils would react to this kind of activity... For me as a teacher it was nice to move from group to group and see how much fun the pupils had...There has been more life and energy in the groups than I had expected...My main concern was to help them with pronunciation. 
Elisabeth commented that the quantity of English in the RT texts was far greater than they were normally used to, especially considering that the pupils were at different levels: "RT showed that they are able to read more text than what we think. We have a tendency to be afraid of giving them too long or too difficult texts."

Elisabeth reflected that one of the major benefits of RT was how it had actively engaged the pupils in an activity that combined the written and oral modes in English. She added: "It is a fun way to learn how to pronounce new words because the activity itself and the texts are enjoyable." The atmosphere in the class had been positive and mistakes were not laughed at. All the pupils felt at ease reading to the others, including the four dyslexic pupils.

All in all, Elisabeth felt that RT had been a positive experience for the pupils. They had become more confident when reading aloud, had read with more passion, and had improved their pronunciation. Elisabeth would recommend RT to other teachers: "I want to present RT for the other teachers, explaining how this project was and what we did, and also how I am thinking about using RT later. I feel that I have acquired a new method for teaching." She added: "The excitement and enthusiasm the pupils showed throughout the week, and especially during the performances, and also the response the audience gave after the performances, shows that RT is without a doubt something we must do again."

\section{Discussion}

For the pupils, RT had largely been a new, positive and enjoyable experience in their roles as both readers and listeners. The largely positive reactions to RT confirmed similar findings among young L1 learners (e.g. Martinez et al., 1999; Millin \& Rinehart, 1999), and the foreign language learners in the study by Chan and Chan (2009). RT had given the pupils a good deal of autonomy, while at the same necessitating a contribution from each one and the need for each one to collaborate. It thus became a shared learning and communicative experience, very much in accordance with Vygotsky's (1978) socio-constructivist principles. Some of the pupils adopted the role of helpers, while others needed help. Again, these roles conformed to the knowledgeable one, or mentor, helping the less knowledgeable one(s) in the sense of Vygotsky's zone of proximal development. For many, the rehearsals had been the most important aspect as it was here that they clearly saw development in their reading. The rehearsals had provided a legitimate reason for several re-readings of the text, i.e. as preparation for the performances. Improvement depended on these re-readings.

The RT project seemed to fulfil the teachers' expectations. For example, Elisabeth found it to be an activity that fostered engagement, enthusiasm and commitment among the pupils. It opened her eyes to what pupils of that age were potentially capable of in English in terms of reading longer texts, realising that she had perhaps previously underestimated their abilities. One of the strengths of RT is that it had included all the pupils in the class (cf. Drew \& Pedersen 2010; 2012; Peebles, 2007), showing its suitability and effectiveness in mixedability classes. It is an activity that Elisabeth was keen to repeat. However, Elisabeth had been 
positive to the project from the outset, had been in the favourable position of having the preparation of the texts done by the first author and also of having a second teacher in the classroom. This situation had reduced the workload that a single teacher with no other help would have experienced and also made it possible for the pupils to receive more support than in a class of the same size with just one teacher. Such practical considerations need to be taken into account when implementing and assessing an RT project.

The observations and analysis of video recordings showed how the pupils' pronunciation, word recognition and fluency improved during the RT cycle, especially among the struggling readers, thereby supporting previous research on the cognitive gains of RT (e.g. Samuels, 1997; Trousdale \& Harris, 1993). This progress may be explained in several ways. Firstly, the pupils were given time and the opportunity to practise thoroughly, thereby supporting the old adage that practice makes perfect. Secondly, the pupils themselves were preoccupied with improvement as they knew they would be performing their text for others. Thirdly, they received corrective feedback from both peers and the teachers. However, the fact that so many words were mispronounced or incorrectly recognised by some of the pupils during the first readings may also be an indication that the vocabulary in the texts, in spite of the fact that a number of words had been simplified from the original, was still nevertheless too difficult. One of the challenges of RT is finding and/or adapting texts to suit the level of the readers, which is more difficult in a mixed ability class. At present, no RT texts that the authors are aware of have been especially written for young EFL learners.

Although comprehension of texts was not studied per se, it is likely that the pupils also learnt the meaning of unfamiliar words during rehearsals of their text (since this was one of the aspects Elisabeth helped them with), in addition to improving the accuracy and fluency of their reading, especially since a list of these words had been provided with each text. What is less certain is how much of the texts the pupils had understood as listeners. Although most of the pupils wrote in their journals that they had understood parts or most of the texts, they may not have understood or been able to guess the meaning of a number of unfamiliar words in each text. What also appeared to be the case was that the groups using a developed RT model, where those reading the roles of characters dramatise while reading, were easier to understand since the use of body language and movement seem to have facilitated comprehension.

As for the affective aspect of RT, the observations clearly indicated strong motivation on the part of the members of each group to work with their texts, thus corroborating other research on affective gains of RT (e.g. Casey \& Chamberlain, 2006; Clementi, 2010; Worthy $\&$ Prater, 2002). The experience also seemed to have a positive effect on motivation to read beyond the RT activity in that the majority of the pupils were motivated to read one or more of the fairy tales on their own. Elisabeth also noticed how the pupils' confidence had increased (cf. Rhinehart, 1999). Increased motivation and confidence can be attributed to the group dynamics in RT, the fact that each reader only reads a small (and therefore manageable) segment at each time, that each reader understands that they are making a contribution to the whole, and that each reader realises that support can be provided from within the group and 
from a teacher. In this way RT can be considered as an activity that includes all pupils, and can be especially beneficial for the motivation and confidence of struggling readers (Chan \& Chan, 2009; Clementi, 2010).

As for limitations, the study was a small-scale one in a single class and the findings cannot therefore be generalised. Moreover, the study also took place in a relatively short and intensive period, during which more time was devoted to English lessons than in a normal week. However, it was not unusual for the pupils in the class to experience intensive teaching in a subject as the two authors are aware that the class experienced an intensive week of Norwegian teaching a month after the completion of the RT project. The outcome may also have been different if a single teacher had been alone with the responsibility of the project without the assistance of a second teacher and a researcher who had prepared the RT texts.

\section{Conclusion}

The study has shown how an RT project with sixth grade EFL learners in Norway has resulted in both cognitive and affective gains for the learners concerned. The study has added to the sparse research on RT with young foreign language learners, while largely supporting the findings of research on RT with young L1 learners. It has shown through the video-recordings comparing the first rehearsals with the performances that RT was able to develop the reading skills of a group of young EFL language learners by considerably reducing the number of their mispronounced and wrongly recognised words and by increasing their reading fluency. The observations and post-project teacher interview indicated that the pupils increased their motivation and confidence in reading aloud. The pupil journals showed how they had enjoyed both performing the texts and listening to others doing so, that RT had had a positive influence on their motivation to read on their own, and that the pupils had experienced growth in their vocabulary. In the post-project interview, the teacher had confirmed the cognitive and affective benefits of the RT project for her pupils. She had been impressed by the positive and constructive atmosphere in the class, by the volume of text the pupils had coped with, by the pupils' active engagement and enthusiasm during the project, and by the way the pupils' reading had developed.

However, this has been a small-scale study conducted during an intense week of English classes. The fact that the teachers involved were positive from the outset and the pupils knew that they would be video-recorded may have influenced the results, although the pupils gradually became much less conscious of the presence of the researcher and camera (it was hardly noticed during the performances, since by then it had become an integral part of the project lessons). It would nevertheless be advantageous to conduct more case studies of RT with primary EFL learners and learners of other foreign languages, since the use of RT with young foreign language researchers is an under-researched area. Possible studies could be to explore RT over a longer time scale than in the present study, the practice of RT with factual texts rather than fairy tales, or to study pupils who write and perform their own RT 


\section{Nordic Journal of Modern Language Methodology}

texts. Such studies would contribute towards gaining a broader understanding of the use and effects of RT with young foreign language learners.

\section{References}

Ary, D., L.C. Jacobs, C. Sorensen, and D. A Walker. 2010. Introduction to research in education ( $9^{\text {th }}$ ed.). Australia: Wadsworth, Cengage Learning.

Black, A., and A. M. Stave. 2007. A comprehensive guide to Readers Theatre: Enhancing fluency and comprehension in middle school and beyond. Newark: International Reading Association.

Bortfeld, H. S., D. Leon, J. E. Bloom, M. F. Schober, and S. E. Brennan. 2001. Disfluency rates in conversation: effects of age, relationship, topic, role, and gender. Language and Speech, 44 (2): 123-147.

Casey, S., and R. Chamberlain. 2006. Bringing reading alive through Readers' Theatre. Illinois Reading Council Journal 34 (4): 17-25.

Chan, A., and S. Chan. 2009. Promoting assessment for learning through Readers Theatre. IATEFL Young Learner and Teenage Special Interest Group 4(09): 40-50.

Clementi, L. B. 2010. Readers Theater: A motivating method to improve reading fluency. Phi Delta Kappan International, 91(5): 85-88.

Coger, L. I., and M. R. White. 1967. Readers theatre handbook. Glenview, Ill: Scott, Foresman and Company.

Day, R.R., and J. Bamford. 1998. Extensive reading in the second language classroom. Cambridge: Cambridge University Press.

Drew, I., and R. R. Pedersen. 2010. Readers Theatre: A different approach to English for struggling readers. Acta Didactica Norge, 4(1): 1-28.

Drew, I., and R. R. Pedersen. 2012. Readers Theatre: a group reading approach to texts in mainstream EFL classes. In Hasselgreen, A., I. Drew, and B. Sørheim (eds.), The young language learner: Research-based insights into teaching and learning. Bergen: Fagbokforlaget.

Dörnyei, Z. 2007. Research methods in applied linguistics: Quantitative, qualitative, and mixed methodologies. Oxford: Oxford University Press.

Forsythe, S. J. 1995. It worked! Readers Theatre in second grade. The Reading Teacher, 49 (3): 264-265.

Gerard, M. 2007. Readers' Theater: Fairy tales. Westminster: Teacher Created Resources.

Hellekjær, G. O. 2007. Reading: From a forgotten to a basic skill. Språk og språkundervisning, 2: 23-29.

Lengeling, M., C. Malarcher, and L. Mills. 1996. The use of Readers Theater in the EFL curriculum. English Teaching Forum, 34(3): 84-86.

Liu, J. 2000. The power of Readers Theater: from reading to writing. ELT Journal 54(4): 


\section{Nordic Journal of Modern Language Methodology}

354-361.

Martinez, M., N. L. Roser, and S. Strecker. 1999. 'I never thought I could be a star': A Readers Theatre ticket to fluency. The Reading Teacher, 52: 326-334.

McKay, M. E. 2008. Readers Theatre - Take another look - It's more than fluency instruction. Learning Landscapes, 2(1): 131-144.

Millin, S. K., and S. D. Rinehart. 1999. Some of the benefits of Readers Theater participation for second-grade Title I students. Reading Research and Instruction, 39 (1): 71-88.

Peebles, J. L. 2007. Incorporating movement with fluency instruction: A motivation for struggling readers. The Reading Teacher, 60(6): 578-581.

Rasinski, T. V. 2010. The fluent reader: Oral \& silent reading strategies for building fluency, word recognition \& comprehension. New York: Scholastic.

Rinehart, S. D. 1999. Don't think for a minute that I'm getting up there: Opportunities for Readers' Theatre in a tutorial for children with reading problems. Journal of Reading Psychology, 20: 71-89.

Samuels, S. J. 1997. The method of repeated readings. The Reading Teacher, 50: 376-381.

Shepard, A. 2004. Readers on stage. Los Angeles: Shepard Publications.

Trousdale, A. M., and V. J. Harris. 1993. Missing links in literary response: Group interpretation of literature. Children's Literature in Education, 24: 195-207.

Tyler, B., and D. J. Chard 2000. Using Readers Theatre to foster fluency in struggling readers: A twist on the repeated reading strategy. Reading and Writing Quarterly, 16: 163-168.

Uthman, L. E. 2002. Readers' theatre: an approach to reading with more than a touch of drama. Teaching PreK-8, 32(6), 56-57.

Vygotsky, L. S. 1978. Mind in society: The development of higher psychological processes. Cambridge: Harvard University Press.

Worthy, J., and K. Prater. 2002. "I thought about it all night": Readers Theatre for reading fluency and motivation. The Reading Teacher, 56(3): 294-297.

Young, C., and T. Rasinski. 2009. Implementing Readers Theatre as an approach to classroom fluency instruction. The Reading Teacher, 63(1): 4-13. 